\title{
Influence of Temperature and Inoculum Density of Fusarium oxysporum f. sp. ciceris on Suppression of Fusarium Wilt of Chickpea by Rhizosphere Bacteria
}

\author{
Blanca B. Landa, Juan A. Navas-Cortés, Ana Hervás, and Rafael M. Jiménez-Díaz
}

First, second, and third authors: Departamento de Protección de Cultivos, Instituto de Agricultura Sostenible (IAS), Consejo Superior de Investigaciones Científicas (CSIC), Apdo. 4084, 14080 Córdoba, Spain; and fourth author: Departamento de Protección de Cultivos, IASCSIC, and Escuela Técnica Superior de Ingenieros Agrónomos y de Montes, Universidad de Córdoba, Apartado 3048, 14080 Córdoba, Spain.

Current address of B. B. Landa: U.S. Department of Agriculture, ARS Root Disease and Biological Control Research Unit, Washington State University, Pullman 99164.

Accepted for publication 16 May 2001.

\section{ABSTRACT}

Landa, B. B., Navas-Cortés, J. A., Hervás, A., and Jiménez-Díaz, R. M. 2001. Influence of temperature and inoculum density of Fusarium oxysporum f. sp. ciceris on suppression of Fusarium wilt of chickpea by rhizosphere bacteria. Phytopathology 91:807-816.

The effects of temperature and inoculum density of Fusarium oxysporum f. sp. ciceris race 5 on suppression of Fusarium wilt in chickpea (Cicer arietinum) cv. PV 61 by seed and soil treatments with rhizobacteria isolated from the chickpea rhizosphere were studied in a model system. Disease development over a range of temperatures $(20,25$, and $30^{\circ} \mathrm{C}$ ) and inoculum densities (25 to 1,000 chlamydospores per gram of soil) was described by the Gompertz model. The Gompertz relative rate of disease progress and final amount of disease increased exponentially and monomolecularly, respectively, with increasing inoculum densities. Disease development was greater at $25^{\circ} \mathrm{C}$ compared with 20 and $30^{\circ} \mathrm{C}$. At 20 and $30^{\circ} \mathrm{C}$, disease development was greater at 250 to 1,000 chlamydospores per gram of soil compared with 25 to 100 chlamydospores per gram of soil. At $25^{\circ} \mathrm{C}$, increasing inoculum densities of the pathogen did not influence disease. Nineteen Bacillus, Paenibacillus, Pseudomonas, and Stenotrophomonas spp. out of 23 bacterial isolates tested inhibited $F$. oxysporum f. sp. ciceris in vitro. Pseudomonas fluorescens RGAF 19 and RG 26, which did not inhibit the pathogen, showed the greatest Fusarium wilt suppression. Disease was suppressed only at 20 or $30^{\circ} \mathrm{C}$ and at inoculum densities below 250 chlamydospores per gram of soil. Bacterial treatments increased the time to initial symptoms, reduced the Gompertz relative rate of disease progress, and reduced the overall amount of disease developed.

Additional keywords: biocontrol agents, disease modeling.
Chickpea (Cicer arietinum L.) is a major source of human and animal high-protein food and the worlds third most important food legume after beans (Phaseolus vulgaris L.) and peas (Pisum sativum L.) (39). Chickpea production is severely limited by Fusarium wilt caused by Fusarium oxysporum Schlechtend.:Fr. f. sp. ciceris (Padwick) Matuo \& K. Sato worldwide (19). Annual chickpea yield losses from Fusarium wilt vary from 10 to $15 \%(19,43)$, but the disease can destroy the crop completely under specific conditions (35).

Management of Fusarium wilt of chickpea has involved the use of resistant cultivars and adjustment of sowing dates $(19,34)$. However, the effectiveness of these management practices is curtailed by the occurrence of races of the pathogen $(16,20,34)$. Seven races of $F$. oxysporum f. sp. ciceris, designated 0 to 6 have been identified $(16,20)$. Races 1 through 4 were first described in India (16). Later, race 0 was reported in California, Spain, and Tunisia; and races 1 and 6 were identified in California, Morocco, and Spain. Race 5, the most virulent of the races occurring in Spain, also occurs in California (20).

The application of rhizobacteria could aid in the management of Fusarium wilt of chickpea when used in combination with resistant cultivars and choice of sowing date. Strains of Pseudomonas

Corresponding author: R. M. Jiménez-Díaz; E-mail address: ag1jidir@uco.es

Publication no. P-2001-0618-01R

(C) 2001 The American Phytopathological Society spp., Burkholderia spp., Bacillus spp., and Paenibacillus spp. (formerly Bacillus spp.) have shown potential in suppression of Fusarium wilt diseases of other crops including chickpea, cotton, and radish $(7,9,17,27,28,38)$. The amount of disease suppression achieved by introduced biocontrol agents is influenced by a number of biotic and abiotic factors such as dose of the agent applied, inoculum density of the pathogen, host genotype, and conduciveness of environment to disease $(3,5,13,18,21,22,26,31,38,40,41)$. Temperature is an especially important factor influencing the success of a biocontrol agent. Studies on this latter subject have dealt primarily with root rot and damping-off diseases $(2,14,32$, 42) or with diseases affecting aerial plant parts $(8,24,36)$, but Fusarium wilt diseases have received little study. Similarly, the incidence and severity of Fusarium wilt of chickpeas also is influenced by multiple factors including the virulence and inoculum density of the pathogen, cultivar susceptibility, and their interactions (33). Severity of the disease is modulated by temperature $(12,34)$, but the precise effect of temperature on disease development is not known. A better understanding of the influence of temperature and inoculum density of $F$. oxysporum f. sp. ciceris on Fusarium wilt development, and how they impact the success of biocontrol agents will enable better predictions of disease development and more efficient uses of biocontrol agents for Fusarium wilt management. The objective of this study was to determine the effect of temperature and inoculum density of $F$. oxysporum f. sp. ciceris race 5 on development of Fusarium wilt of chickpea and biocontrol activity of rhizobacteria isolated from the chickpea rhizosphere. 


\section{MATERIALS AND METHODS}

Fungal isolate and inoculum production. The monoconidial isolate Foc 8012 of F. oxysporum f. sp. ciceris race 5 used in this study was obtained from an infected chickpea in southern Spain and has been used previously $(17,33)$. Isolate Foc 8012 was stored in sterile soil tubes at $4^{\circ} \mathrm{C}$. Active cultures were obtained by placing small aliquots of a soil culture onto a plate of fresh potato dextrose agar (PDA) (250 g of unpeeled potatoes, $20 \mathrm{~g}$ of agar, and $20 \mathrm{~g}$ of glucose per liter of distilled water) and incubating for 5 days at $25^{\circ} \mathrm{C}$ with a 12-h photoperiod of fluorescent and near$\mathrm{UV}$ light at $36 \mu \mathrm{E} \mathrm{m}^{-2} \mathrm{~s}^{-1}$. Inoculum for in planta assays consisted of chlamydospores obtained as previously described (18). Chlamydospores were stored in sterile soil at $4^{\circ} \mathrm{C}$.

Bacterial isolates and inoculum production. Seventeen Bacillus spp., three Paenibacillus spp., two Pseudomonas fluorescens isolates, and one Stenotrophomonas maltophilia isolate were used in this study (Table 1). These isolates are representative of bacteria that demonstrated in vitro antagonism against $F$. oxysporum f. sp. ciceris race 5 in a previous study (25). Bacteria were isolated from rhizosphere soil and roots of chickpea cultivars grown in soil from two fields either with or without a history of chickpea and Fusarium wilt (25). The bacterial isolates were characterized to species by the API 50CHB, API 20E, and API 20NE identification systems (SA Montalieu, Vercieu, France) (25). Bacterial cells from cultures in Luria-Bertani broth medium (30) were stored in $25 \%$ glycerol at $-80^{\circ} \mathrm{C}$. Active cultures were obtained by streaking bacteria from stock cultures onto PDA (Difco Laboratories, Detroit) (Bacillus spp., Paenibacillus spp., and $S$. maltophilia isolates) or King's B agar (KBA) (Pseudomonas fluorescens isolates) (23) and incubating at $28^{\circ} \mathrm{C}$ for $48 \mathrm{~h}$.

Inocula of Bacillus spp., Paenibacillus spp., and S. maltophilia isolates used to treat seed or soil were produced in 250-ml flasks with potato dextrose broth (Difco Laboratories) at $\mathrm{pH} 7.0$ on an orbital shaker (Adolf Kühner AG, Birsfelden, Switzerland) at $125 \mathrm{rpm}$ and $28^{\circ} \mathrm{C}$ for 3 days. Cells were harvested by centrifugation $(10,500 \times g, 20 \mathrm{~min})$. Inocula of Pseudomonas fluorescens isolates were grown on KBA at $28^{\circ} \mathrm{C}$ for $48 \mathrm{~h}$, were scraped from the medium with a sterile glass rod, and suspended in $0.1 \mathrm{M}$ $\mathrm{MgSO}_{4}$. Bacterial suspensions were centrifuged $(10,500 \times g$, $20 \mathrm{~min}$ ) twice in sterile distilled water to remove residual metabolites and trace of nutrients and resuspended in $0.1 \mathrm{M} \mathrm{MgSO}_{4}$ to a final concentration of approximately $10^{10} \mathrm{CFU} / \mathrm{ml}$.

Bacteria seed and soil treatments. Chickpea cv. PV 61 ("kabuli" type, ram head-shaped, beige seed) susceptible to $F$. oxysporum f. sp. ciceris race 5 (33) was used. Seeds were surfacedisinfested in $2 \% \mathrm{NaOCl}$ for $3 \mathrm{~min}$, washed three times in sterile distilled water, and dried for $6 \mathrm{~h}$ under a stream of filtered air. For seed treatment, $1.5 \mathrm{ml}$ of a bacterial cell suspension was mixed with $10 \mathrm{~g}$ of chickpea seeds in a 500-ml Erlenmeyer flask. The mixture was rotatory shaken by hand until the suspension was fully absorbed by the seeds, and the seeds were air dried under a stream of filtered air. The control treatment consisted of seeds treated with $0.1 \mathrm{M} \mathrm{MgSO}_{4}$ only. To determine bacterial dose on the seed, five seeds of each treatment were each placed in a tube with $10 \mathrm{ml}$ of sterile distilled water and sonicated for $10 \mathrm{~min}$. Serial dilutions of the suspensions were plated onto salt V8 agar Bacillus-semiselective medium (44), PDA, and modified KBA

TABLE 1. Effect of bacterial isolates from the chickpea rhizosphere on development of Fusarium wilt in chickpea cv. PV 61 sown in soil infested with Fusarium oxysporum $\mathrm{f}$. sp. ciceris race 5

\begin{tabular}{|c|c|c|c|c|c|}
\hline \multirow[b]{2}{*}{ Bacterial isolate $^{\mathrm{a}}$} & \multicolumn{5}{|c|}{ Element of disease progress curve } \\
\hline & $t_{\mathrm{is}} \pm \mathrm{SE}^{\mathrm{b}}$ & $\mathrm{DII}_{\text {final }} \pm \mathrm{SE}^{\mathrm{b}}$ & $\mathrm{SAUDPC} \pm \mathrm{SE}^{\mathrm{b}}$ & $r_{G} \pm \mathrm{SE}^{\mathrm{c}}$ & $\mathrm{HG} \pm \mathrm{SE}^{\mathrm{d}}$ \\
\hline Bacillus subtilis RGAF 3 & $21.1 \pm 0.6^{*}$ & $0.934 \pm 0.038$ & $0.641 \pm 0.046$ & $0.451 \pm 0.008$ & $1.980 \pm 0.130 *$ \\
\hline Bacillus amyloliquefaciens RGAF 4 & $20.0 \pm 0.4^{*}$ & $0.941 \pm 0.026$ & $0.617 \pm 0.040$ & $0.318 \pm 0.018$ & $1.780 \pm 0.057 *$ \\
\hline Bacillus circulans RGAF 6a & $21.8 \pm 0.7^{*}$ & $0.854 \pm 0.051$ & $0.533 \pm 0.035$ & $0.361 \pm 0.017$ & $1.955 \pm 0.063^{*}$ \\
\hline Bacillus circulans RGAF $6 \mathrm{~b}$ & $21.2 \pm 0.3^{*}$ & $0.962 \pm 0.014$ & $0.644 \pm 0.026$ & $0.416 \pm 0.016$ & $1.600 \pm 0.079 *$ \\
\hline Bacillus licheniformis RGAF 7 & $18.3 \pm 1.1^{*}$ & $0.896 \pm 0.038$ & $0.535 \pm 0.031$ & $0.299 \pm 3 \times 10^{-4}$ & $1.770 \pm 0.259^{*}$ \\
\hline Bacillus amyloliquefaciens RGAF 13 & $19.3 \pm 0.5$ & $0.996 \pm 0.003$ & $0.682 \pm 0.029$ & $0.518 \pm 0.005$ & $1 * *$ \\
\hline Bacillus subtilis RGAF 14 & $21.0 \pm 0.4 *$ & $0.993 \pm 0.005$ & $0.662 \pm 0.017$ & $0.476 \pm 1 \times 10^{-5}$ & $1.683 \pm 0.129 *$ \\
\hline Pseudomonas fluorescens RGAF 19 & $22.2 \pm 0.9 *$ & $0.806 \pm 0.051 *$ & $0.465 \pm 0.042 *$ & $0.214 \pm 0.023 *$ & $3.001 \pm 0.214$ \\
\hline Bacillus circulans RG 24 & $21.4 \pm 0.4^{*}$ & $0.941 \pm 0.023$ & $0.574 \pm 0.029$ & $0.363 \pm 0.024$ & $1 * *$ \\
\hline Pseudomonas fluorescens RG 26 & $22.1 \pm 0.6^{*}$ & $0.785 \pm 0.077 *$ & $0.470 \pm 0.066^{*}$ & $0.243 \pm 0.014 *$ & $1 * *$ \\
\hline Bacillus subtilis RG 32 & $21.0 \pm 0.4^{*}$ & $0.967 \pm 0.015$ & $0.646 \pm 0.030$ & $0.457 \pm 4 \times 10^{-7}$ & $1.670 \pm 0.098^{*}$ \\
\hline Paenibacillus polymyxa RGAF 84 & $21.2 \pm 0.4^{*}$ & $0.934 \pm 0.037$ & $0.665 \pm 0.056$ & $0.482 \pm 0.019$ & $2.040 \pm 0.055^{*}$ \\
\hline Paenibacillus macerans RGAF 101 & $21.8 \pm 0.4 *$ & $0.861 \pm 0.028$ & $0.513 \pm 0.026$ & $0.431 \pm 6 \times 10^{-6}$ & $1.750 \pm 0.071^{*}$ \\
\hline Bacillus licheniformis RGAF 102 & $19.7 \pm 0.5^{*}$ & $0.993 \pm 0.004$ & $0.694 \pm 0.022$ & $0.420 \pm 0.013$ & $1.700 \pm 0.146^{*}$ \\
\hline Control & $17.3 \pm 0.6$ & $0.969 \pm 0.021$ & $0.634 \pm 0.028$ & $0.267 \pm 8 \times 10^{-7}$ & $3.016 \pm 0.177$ \\
\hline MSD Dunnett's test & 2.3 & 0.141 & 0.156 & $\ldots$ & 0.226 \\
\hline
\end{tabular}

${ }^{a}$ Bacterial isolates were previously characterized to species (25) by the conventional API 50CHB, API 20E, and API 20NE identification systems (SA Montalieu, Vercieu, France). Bacteria were applied to the seed and to the soil.

${ }^{\mathrm{b}} t_{\mathrm{is}}=$ time in days to initial symptoms; DII $\mathrm{final}_{\mathrm{l}}=$ disease intensity index (DII) determined at the final date of disease assessment; SAUDPC $=$ area under disease intensity progress curve estimated by the trapezoidal integration method standardized by duration time in days; and SE = standard error. Data are mean of six randomized blocks each with three pots and four plants per pot. Means in a column followed by an asterisk are significantly different $(P<0.05)$ than that of the control according to Dunnett's test.

${ }^{\mathrm{c}} r_{G}=$ estimated values of the relative rate parameter of the Gompertz model adjusted to DII progress over time. The standard errors of $r_{G}$ obtained from regression analyses were used to compare the effects of experimental treatments. Values followed by an asterisk are significantly lower $(P<0.05)$ than that of the control.

${ }^{\mathrm{d}} \mathrm{HG}=$ in vitro hyphal growth of $F$. oxysporum f. sp. ciceris race 5 in dual culture with each bacterial isolate. Data are mean of 10 replicated plates. Means followed by an asterisk are significantly different $(P<0.05)$ from that of the control according to Dunnett's test. ** indicates that no inhibition was recorded as the advancing edge of the fungal colony reached the edge of the bacterium colony. 
(11) and incubated as previously described to determine populations of Bacillus, Paenibacillus, S. maltophilia, and Pseudomonas fluorescens isolates, respectively. Treated seeds yielded $10^{7}$ to $6 \times$ $10^{8} \mathrm{CFU}$ per seed depending upon the bacterial isolate. Seed of the control treatment yielded no bacterial colonies. For soil treatment, $25 \mathrm{~g}$ of heat-sterilized talcum powder was infested with $10 \mathrm{ml}$ of a bacterial suspension, and the mixture was dried at $30^{\circ} \mathrm{C}$ in an incubator for 5 to 7 days. Bacterial populations in the infested talcum powder enumerated by dilution plating as previously described ranged from $1.7 \times 10^{8}$ to $1.6 \times 10^{10} \mathrm{CFU} / \mathrm{g}$ of talcum, depending on the bacterial isolate.

Dual cultures. Bacterial strains were tested for their ability to inhibit the hyphal growth of $F$. oxysporum $\mathrm{f}$. sp. ciceris race 5 in vitro. Assays were performed in petri plates containing $20 \mathrm{ml}$ of PDA. Two bacterial isolates were spotted per plate, $1 \mathrm{~cm}$ from the opposite edges of the plate and opposite each other. Bacteria were incubated at $28^{\circ} \mathrm{C}$ for $48 \mathrm{~h}$ and one agar disk, cut from the leading edge of a 5-day-old fungal culture on PDA, was placed in the center of the plate. The bacterial and fungal isolates were plated separately as controls. Plates were incubated at $28^{\circ} \mathrm{C}$ for 5 days, and the length of hyphal growth toward the bacteria and that of a control plate were measured. Each combination of microorganisms and controls were replicated five times in a randomized complete block design. The experiment was repeated once, and the pooled data from the two experiments were analyzed by analysis of variance.

Suppression of Fusarium wilt by bacteria. A preliminary experiment was conducted to determine the ability of each of the 23 bacterial isolates to suppress Fusarium wilt of cv. PV 61 by applying them as a combination of seed and soil treatment. The combination was used because it provided more consistent suppression bacterial treatments (25). Chickpea seeds treated with a bacterial isolate were sown in 15-cm-diameter clay pots (four seeds per pot) filled with an autoclaved $\left(121^{\circ} \mathrm{C}, 1 \mathrm{~h}\right.$, twice, on two consecutive days) soil mixture (clay loam/peat, 2:1, vol/vol) artificially infested with 0 or 500 chlamydospores of isolate Foc 8012 per gram of soil and amended with the same bacterial isolate as the seed treatment at approximately $1 \times 10^{6} \mathrm{CFU} / \mathrm{g}$ of soil. Seeds treated with $0.1 \mathrm{M} \mathrm{MgSO}_{4}$ and sown in soil mixture infested or not with the pathogen and amended with talcum powder served as controls. The soil mixture was autoclaved to eliminate the impact of the activity of the indigenous soil microflora that would vary among soil temperatures. The four treatments were (bacterial treatment/pathogen infestation) (i) nontreated seed + soil/noninfested soil; (ii) nontreated seed + soil/infested soil; (iii) treated seed + soil/noninfested soil; and (iv) treated seed + soil/infested soil. The actual bacterial and pathogen inoculum densities in the infested soil mixture were determined by dilution plating just after sowing. For F. oxysporum f. sp. ciceris race 5, serial dilutions of a soil suspension in sterile distilled water were plated onto V8 juice-oxgall-PCNB agar (VOPA) Fusariumselective medium (4) and incubated at same conditions that pure cultures for 3 to 7 days. For the bacterial isolates, dilution plating and incubation conditions were the same as those previously described. Inoculum densities of bacterial isolates ranged from $1 \times$ $10^{5}$ to $5 \times 10^{6} \mathrm{CFU} / \mathrm{g}$ of soil depending upon isolates. Plants were incubated in a growth chamber adjusted to $25 \pm 1{ }^{\circ} \mathrm{C}, 60$ to $90 \%$ relative humidity, and a 14-h photoperiod of fluorescent light at $360 \mu \mathrm{E} \mathrm{m}^{-2} \mathrm{~s}^{-1}$ for 32 days. Plants in a pot were watered as needed and fertilized with $100 \mathrm{ml}$ of a $0.1 \%, 20-5-32+$ micronutrients hydro-sol fertilizer (Haifa Chemicals Ltd., Haifa, Israel) solution every week. Treatments in the experiment comprised two levels of pathogen inoculum density and 24 levels of bacterial isolates. There were three replicated blocks in a randomized complete block design, each treatment consisting of 12 plants (three pots and four plants per pot). The experiment was repeated once, and the pooled data from the two experiments were analyzed by analysis of variance.
Influence of pathogen inoculum density and temperature on suppression of Fusarium wilt by bacteria. Of the 23 original bacterial isolates, Pseudomonas fluorescens RGAF 19, Pseudomonas fluorescens RG 26, Bacillus megaterium RGAF 51, and Paenibacillus macerans RGAF 101 were selected for further study. The criteria for selection was based on the isolates ability to suppress disease caused by $F$. oxysporum f. sp. ciceris race 5, as well as to either inhibit (isolates RGAF 51 and RGAF 101) or not inhibit (isolates RGAF 19 and RG 26) in vitro hyphal growth of the pathogen. Each of the four bacteria was used for joint seed and soil treatment as previously described. Seeds of 'PV 61' chickpea treated with a bacterium as previously described (four seeds per pot) were sown in autoclaved soil mixture infested with $0,25,50$, $100,250,500$, and 1,000 chlamydospores of isolate Foc 8012 per gram of soil and amended with approximately $1 \times 10^{6} \mathrm{CFU} / \mathrm{g}$ of soil of the same bacterium as the seed treatment. Seeds treated with $0.1 \mathrm{M} \mathrm{MgSO}_{4}$ and sown in the autoclaved soil mixture infested with the same pathogen inoculum density and amended with $1.5 \mathrm{~g}$ of talcum powder per gram of soil served as controls. Thus, there were five treatments per pathogen inoculum density. The actual inoculum density of Foc 8012 and the bacteria in the infested soil mixture, and that of the bacteria on chickpea seeds, were determined by dilution plating just after sowing as previously described. Cell densities of bacteria ranged from $0.6 \times 10^{6}$ to $2.3 \times 10^{6} \mathrm{CFU} / \mathrm{g}$ of soil and from $1.5 \times 10^{8}$ to $3.6 \times$ $10^{8} \mathrm{CFU}$ per seed, depending on the experiment and bacterial isolate. Similarity of bacteria and pathogen inoculum densities within a treatment among temperatures was tested by analysis of variance with temperatures as blocks. There were no significant differences $(P>0.05)$ for bacteria or pathogen inoculum densities among temperatures, which allowed combining data for variance and regression analyses. Plants were grown in a growth chamber adjusted to each of $20 \pm 1{ }^{\circ} \mathrm{C}, 25 \pm 1^{\circ} \mathrm{C}$, and $30 \pm 1^{\circ} \mathrm{C}, 60$ to $90 \%$ relative humidity, and a 14-h photoperiod of fluorescent light at $360 \mu \mathrm{E} \mathrm{m}^{-2} \mathrm{~s}^{-1}$ for 60 days. Plants were watered as needed and fertilized weekly as previously described. There was a separate experiment for each temperature, with the whole set of experiments arranged following a split-plot design. In this design, temperatures were main plots and the factorial combinations of seven levels of pathogen inoculum density and five levels of bacterial antagonists were subplots. There were four blocks, each one comprising three pots (four plants per pot). In each separate experiment, the combination of 50 and 1,000 chlamydospores per gram of soil and the five levels of bacterial antagonists incubated at $25 \pm 1{ }^{\circ} \mathrm{C}$ were additionally included to test reproducibility of results. Analysis of variance of treatments common to the experiments showed no significant differences $(P>0.05)$ among experiments. Further analyses were performed using the pooled data from the three experiments.

Disease assessment and data analyses. In all experiments, disease incidence and severity were assessed at 2- to 3-day intervals. Severity of symptoms on individual plants were rated on a scale from 0 to 4 according to percentage of foliage with yellowing or necrosis in acropetal progression: $0=0 \%, 1=1$ to $33 \%, 2=34$ to $66 \%, 3=67$ to $100 \%$, and $4=$ dead plant, as used previously $(17,33)$. Upon termination of experiments, isolations were made from stem segments of symptomless plants to determine the occurrence of vascular infections. Stem pieces were cut into 5- to $10-\mathrm{mm}$ pieces, surface-disinfested in $0.2 \% \mathrm{NaOCl}$ for $2 \mathrm{~min}$, plated on VOPA, and incubated at $25^{\circ} \mathrm{C}$ with a 12-h photoperiod of fluorescent and near-UV light at $36 \mu \mathrm{E} \mathrm{m}^{-2} \mathrm{~s}^{-1}$ for 3 to 5 days. Incidence and severity ( 0 to 4 scale) data within a pot were used to calculate a disease intensity index (DII) by the equation DII = $\left(\Sigma S_{i} N_{i}\right) 4^{-1} N_{t}$, where $S_{i}=$ symptom severity, $N_{i}=$ number of plants with $S_{i}$ symptom severity, and $N_{t}=$ total number of plants $(17,18$, 33). Thus, DII expresses the mean value of disease intensity at any given moment as a proportion of the maximum possible disease. Disease progress curves were obtained from the accumulated DII 
over time in days from the date of sowing. In the preliminary experiments to screen bacterial isolates for Fusarium wilt suppression, the nonlinear form of the Richards and Gompertz models was evaluated for goodness-of-fit to the set of DII progress data using nonlinear regression analysis. The Richards model, a generalized form of growth curve, offered an improved fit to disease progression data compared with the Gompertz model, which lacks the shape parameter. However, for most of the DII progress curves studied, the estimated value of the Richards function's shape parameter was not significantly different from 1 . Because the Richards model becomes closer to Gompertz model as the shape parameter approaches $1(6,29)$, the Gompertz function was used for further analyses. In the Gompertz equation, $\operatorname{DII}(t)=$ $K_{G} \exp \left[-B \exp \left(-r_{G} \times t\right)\right]$, in which DII = disease intensity index, $K_{G}=$ asymptote parameter, $B=$ constant of integration, $r_{G}=$ relative rate of disease increase, and $t=$ time of disease assessment in days after sowing. In this model, the time taken to reach the inflection point $\left(t_{\text {ip }}\right)$ is given by $t_{\text {ip }}=\ln (B) / r_{G}$ (29). For analyses, nonzero points for DII in experimental units and the average DII values of the replicated blocks were used. The standard errors of the $r_{G}$ obtained from regression analyses were used to compare the effects of experimental treatments. To better analyze the effect of the experimental factors on disease, we developed a response surface for DII progression as a function of both time from sowing and inoculum density for the different incubation temperaturesbacterial treatments with a two-stage method $(15,33)$. Using the Gompertz equation in the first step, the time component was separately analyzed for each inoculum density data subset. In the second step, the influence of the inoculum density on the estimated values of the three Gompertz parameters, the asymptotic DII $\left(K_{G}\right)$, the constant of integration $(B)$, and the rate parameter $\left(r_{G}\right)$ were analyzed.

Disease development in the preliminary experiment using 24 bacterial treatments was characterized by four variables associated with disease progress curves: (i) $t_{\text {is }}=$ incubation period for disease development, established as the time in days to initial symptoms; (ii) final disease intensity $\left(\mathrm{DII}_{\text {final }}=\mathrm{DII}\right.$ observed at the final date of disease assessment); (iii) standardized area under the DII progress curve (SAUDPC) calculated by trapezoidal integration method and standardized by duration of disease development in days (6); and (iv) $r_{G}=$ obtained by the estimates of parameters of the Gompertz model fitted to DII progress data. The effect of bacterial treatments on the incubation period, SAUDPC, and in vitro hyphal growth of $F$. oxysporum f. sp. ciceris race 5 was determined by analysis of variance using the general linear model procedure of SAS (version 6.11, SAS Institute, Cary, NC). The Dunnett's two-tailed $t$ test was used to determine significant dif-

TABLE 2. Correlation coefficients for the in vitro hyphal growth inhibition of Fusarium oxysporum f. sp. ciceris race 5 by bacterial isolates and four elements used to characterize Fusarium wilt progress curves developed in chickpea after bacterial treatments $^{\mathrm{a}}$

\begin{tabular}{lccccc}
\hline Variable $^{\mathrm{b}}$ & $t_{\text {is }}$ & DII $_{\text {final }}$ & SAUDPC & $r_{G}$ & HG \\
\hline$t_{\text {is }}$ & 1.000 & $\underline{-0.500}$ & -0.363 & 0.270 & -0.063 \\
DII & $\ldots$ & 1.000 & $\underline{0.935}$ & $\underline{0.496}$ & -0.288 \\
SAUDPC & $\ldots$ & $\ldots$ & 1.000 & $\underline{0.612}$ & -0.332 \\
$r_{G}$ & $\ldots$ & $\ldots$ & $\ldots$ & 1.000 & -0.228 \\
HG & $\ldots$ & $\ldots$ & $\ldots$ & $\ldots$ & 1.000 \\
\hline
\end{tabular}

a Based on data from 23 disease progress curves from Table 1. Numbers underlined are statistically significant $(P<0.05)$.

b Values for a bacterial treatment relative to that in the control treatment:

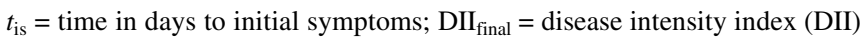
determined at the final date of disease assessment; SAUDPC = area under disease intensity progress curve estimated by the trapezoidal integration method standardized by duration time in days; $r_{G}=$ estimates of rate parameter of the Gompertz model adjusted to DII progress over time; and $\mathrm{HG}=$ in vitro hyphal growth of $F$. oxysporum $\mathrm{f}$. sp. ciceris race 5 in dual culture with each bacterial isolate. ferences between bacterial treatments and the control in soil infested with the pathogen $(P<0.05)$.

To describe the effects of inoculum density (ID) on the $t_{\text {is }}$ for disease developed with different bacterial treatments and incubation temperatures, the expanded negative exponential model, $t_{\text {is }}($ ID) $=C \exp [-r \times \log ($ ID) $)]+K$ was fitted to data as described by Navas-Cortés et al. (33). In this model, $t_{\text {is }}=$ the incubation period in days, $C=$ constant, $r=$ rate of $t_{\text {is }}$ decrease, ID = inoculum density in soil, and $K=$ asymptote parameter for the minimum $t_{\text {is. }}$

Regression analyses were conducted with the least-squares program for nonlinear models (NLIN) procedure of SAS. The coefficient of determination $\left(R^{2}\right)$, the mean square error, the standard errors associated with the parameter estimates, confidence intervals of predicted values, and pattern of the standardized residuals plotted against either predicted values or the independent variable were used to evaluate the appropriateness of a model to describe the data $(6,29)$.

\section{RESULTS}

In vitro hyphal inhibition of $F$. oxysporum $\mathbf{f}$. sp. ciceris race 5 and suppression of Fusarium wilt. Nineteen Bacillus, Paenibacillus, Pseudomonas, and Stenotrophomonas spp. of the 23 bacterial isolates in the study significantly $(P<0.05)$ inhibited the in vitro hyphal growth of $F$. oxysporum f. sp. ciceris race 5 . However, the extent of inhibition varied among isolates (Table 1). Bacillus amyloliquefaciens RGAF 13, Bacillus circulans RG 24, and Pseudomonas fluorescens isolates RGAF 19 and RG 26 did not inhibit the pathogen significantly $(P \geq 0.05)$.

There were no symptoms in control plants nor in plants from seed treated with bacteria grown in soil treated, but noninfested with the pathogen (data not shown). In control plants grown in infested soil, symptoms characteristic of wilting caused by $F$. oxysporum f. sp. ciceris race 5 developed 17 days after inoculation. Severe disease developed reaching $\mathrm{DII}_{\text {final }}$ of 0.969 and SAUDPC of 0.634 (Table 1). Bacteria varied in their ability to suppress Fusarium wilt in 'PV 61' chickpea; the DII final $_{\text {and SAUDPC }}$ in treated plants ranged from 0.785 to 0.996 and 0.465 to 0.705 , respectively (Table 1). Pseudomonas fluorescens RGAF 19 and RG 26 showed the greatest disease suppression among tested isolates and significantly $(P<0.05)$ reduced the $\mathrm{DII}_{\text {final }}$ by 16 and $19 \%$, and SAUDPC by 26.7 and $25.9 \%$, respectively. However, all bacterial isolates except for Bacillus megaterium RGAF 12 and Bacillus amyloliquefaciens RGAF 13 significantly $(P<0.05)$ delayed the incubation period by 1 to 5 days (Table 1 ). The Gompertz model adequately described all DII progress curves in the experiment $\left(R^{2}>0.99\right)$, with the relative rate of DII increase $\left(r_{G}\right)$ in the fitted curves ranging from 0.214 to 0.518 .

Relatively high correlation was found among some of the four elements from DII progress curves (DII $\mathrm{final}_{\text {ina }}, t_{\mathrm{is}}, \mathrm{SAUDPC}$, and $r_{G}$ ). DII $_{\text {final }}$ and SAUDPC $(r=0.935)$ were the curve elements with the highest correlation coefficient, followed by SAUDPC and $r_{G}(r=$ $0.61)$ and $\mathrm{DII}_{\text {final }}$ and $r_{G}(r=0.496)$. There was no significant correlation $(P>0.05)$ between any of the four DII progress curve elements and the in vitro pathogen hyphal growth (Table 2).

Four of the twenty-three bacterial isolates, including Bacillus megaterium RGAF 51, Paenibacillus macerans RGAF 101, Pseudomonas fluorescens RGAF 19, and Pseudomonas fluorescens RG 26, were chosen for further experiments. Pseudomonas fluorescens RGAF 19 and Pseudomonas fluorescens RG 26 are representative of bacteria that did not inhibit the in vitro pathogen hyphal growth but significantly suppressed Fusarium wilt. Bacillus megaterium RGAF 51 and Paenibacillus macerans RGAF 101 are representative of bacteria that significantly reduced the in vitro pathogen hyphal growth but did not suppress the disease (Table 1).

Because there were differences among the actual inoculum densities of bacteria established on seed and in soil for treatments in 


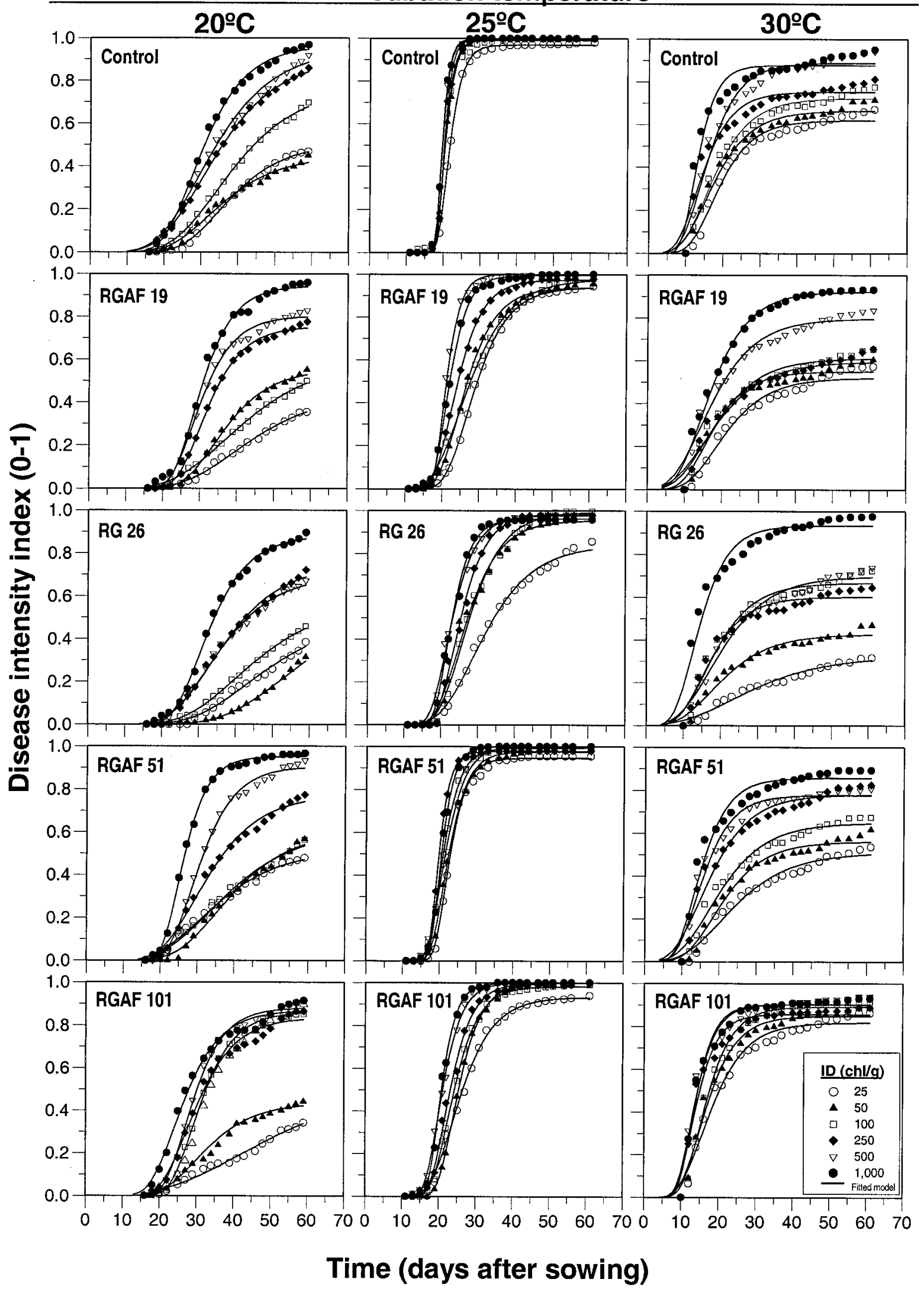

Fig. 1. Effect of bacterial treatments on development of Fusarium wilt in chickpea cv. PV 61 grown in soil infested with an inoculum density (ID) of 25,50 , $100,250,500$, and 1,000 chlamydospores per gram (chl/g) of soil of Fusarium oxysporum f. sp. ciceris race 5 and incubated at 20,25 , and $30^{\circ} \mathrm{C}$. Bacteria tested were Pseudomonas fluorescens RGAF 19, Pseudomonas fluorescens RG 26, Bacillus megaterium RGAF 51, and Paenibacillus macerans RGAF 101. Nontreated seeds sown in nontreated soil served as controls. Each point represents the mean disease intensity index of four replications each with three pots and four plants per pot. Lines represent the predicted disease progress curves calculated by the Gompertz equation. 
the experiment, a correlation analysis was performed between the actual inoculum densities established on treated seed and soil and the $t_{\text {is }}, \mathrm{DII}_{\text {final }}$, SAUDPC, and $r_{G}$ values for DII progress curves associated with the treatments. There was no significant correlation $(P>0.118)$ between any of the above variables and the bacterial inoculum density achieved in soil (data not shown). However, a low but significant negative correlation $(P<0.012)$ was found between bacterial inoculum density on seed and the DII $\mathrm{final}_{\text {fina }}$ $(r<0.61)$ and SAUDPC $(r<0.52)$. Efforts were made to minimize variability in the inoculum densities of bacterial isolates on seeds and in soil treatments in further experiments.

Influence of pathogen inoculum density and incubation temperature on suppression of Fusarium wilt by bacteria. The inoculum density of $F$. oxysporum $\mathrm{f}$. sp. ciceris, incubation temperature, and bacterial treatment (RGAF 19, RG 26, RGAF 51, and RGAF 101) influenced the development of Fusarium wilt in 'PV 61' chickpea. Symptoms did not develop in control plants, or in plants from treated seeds grown in treated, noninfested soil (data not shown). Disease in control plants grown in infested soil was favored at $25^{\circ} \mathrm{C}$ compared with 20 and $30^{\circ} \mathrm{C}$; however, there was a significant $(F=16.73 ; P<0.0001)$ incubation temperaturepathogen inoculum density interaction in disease development.

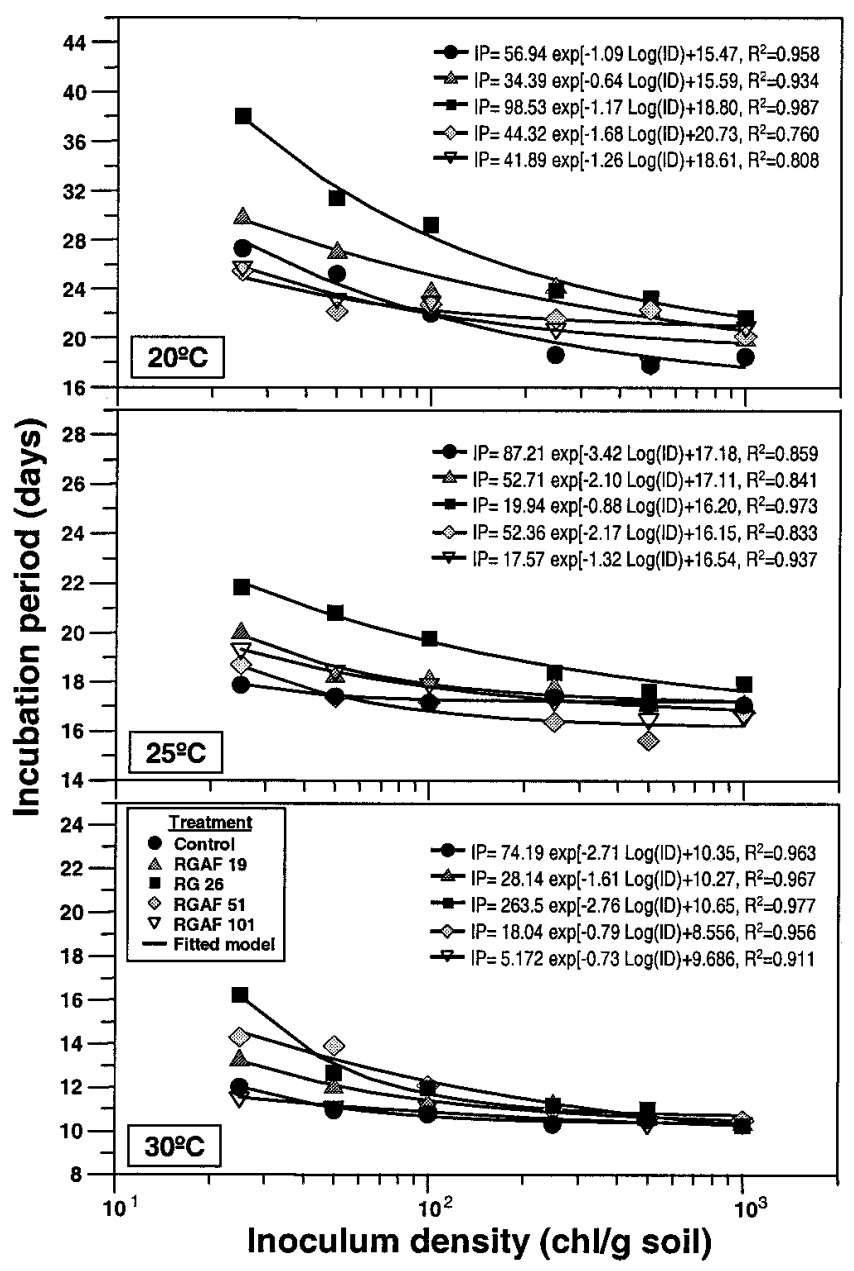

Fig. 2. Relationship between the inoculum density (ID) $(25,50,100,250$, 500 , and 1,000 chlamydospores per gram [chl/g] of soil) of Fusarium oxysporum $\mathrm{f}$. sp. ciceris race 5 and the time to initial symptoms (incubation period, IP) of Fusarium wilt in chickpea cv. PV 61 incubated at 20, 25, and $30^{\circ} \mathrm{C}$ after treatment with Pseudomonas fluorescens RGAF 19, Pseudomonas fluorescens RG 26, Bacillus megaterium RGAF 51, and Paenibacillus macerans RGAF 101. Nontreated seeds sown in nontreated soil served as controls. Each point represents the mean data of four replications each with three pots and four plants per pot. The line represents the predicted function calculated by the expanded negative exponential model.
Thus, at $25^{\circ} \mathrm{C}$, disease development was not influenced to any significant extent $(F=1.00 ; P=0.4509)$ by increasing inoculum densities of $F$. oxysporum f. sp. ciceris; however, there was a significant increase in $\mathrm{DII}_{\text {final }}$ with the increase in inoculum density at $20^{\circ} \mathrm{C}(F=10.22 ; P=0.0002)$ and $30^{\circ} \mathrm{C}(F=7.17 ; P=$ 0.0013) (Fig. 1). Treatments with Pseudomonas fluorescens RGAF 19 and RG 26 enhanced the disease reduction effect caused by the less favorable incubation temperatures. Thus, overall disease suppression by these bacteria was significantly greater $(F=$ 48.55; $P=0.0002)$ at 20 and $30^{\circ} \mathrm{C}$ than at $25^{\circ} \mathrm{C}$, and this effect was strong $(F=81.88 ; P<0.0001)$ at inoculum densities of $F$. oxysporum f. sp. ciceris below 250 chlamydospores per gram of soil (Fig. 1).

Disease developed earlier as inoculum density of $F$. oxysporum f. sp. ciceris increased, and the time to initial symptoms $\left(t_{\text {is }}\right)$ decreased exponentially with this increase (Fig. 2) for all four bacterial treatments. The largest differences in the $t_{\text {is }}$ occurred among incubation temperatures $(F=1030.13 ; P<0.0001)$, irrespective of bacterial treatment or inoculum density of the pathogen in soil. Thus, the shortest and longest $t_{\text {is }}$ occurred at 30 and $20^{\circ} \mathrm{C}$, respectively. For disease reactions within a comparable range of inoculum density of the pathogen, the $t_{\text {is }}$ was increased significantly $(P<0.05)$ by treatments with Pseudomonas fluorescens RGAF 19 and RG 26 compared with the control treatment at all incubation temperatures (Fig. 2).

The Gompertz model adequately described all DII progress curves obtained for the incubation temperature $\times$ bacterial treatment $\times$ inoculum density combinations $\left(R^{2}>0.98\right)$ (Fig. 1$)$. In this model, the estimated values of asymptote parameter, $K_{G}$, was related to inoculum density (ID) by the monomolecular model $K_{G}(\mathrm{ID})=c_{1}\left\{1-c_{2} \exp \left[-c_{3} \times \log (\mathrm{ID})\right]\right\}$ (data not shown); and the estimated values for the rate parameter, $r_{G}$, showed an exponential increase with increasing inoculum densities in soil according to $r_{G}(\mathrm{ID})=c_{5}+c_{6} \exp \left[c_{7} \times \log (\mathrm{ID})\right]$ (data not shown). As expected, no relationship was found between the estimated values for the third parameter, $B$, and therefore, $B$ can be regarded as a constant, i.e., $B\left(\right.$ ID) $=c_{4}$. Based on results from the two-stage method, a response surface could be determined directly from the original data set (15) with the equation DII $(t$, ID) $=$ $K_{G}$ (ID) $\exp \left\{-B\right.$ (ID) $\exp \left[r_{G}\right.$ (ID) $\left.\left.t\right]\right\}$ (Fig. 3). Parameters $\left(c_{1}\right.$ to $\left.c_{7}\right)$ in this equation were simultaneously estimated for each incubation temperature-bacterial isolate combination. Response surfaces for the increase of Fusarium wilt DII in chickpea cv. PV 61 incubated at 20,25 , and $30^{\circ} \mathrm{C}$ after seed + soil treatment with Pseudomonas fluorescens RG 26 and in the controls (nontreated seeds sown in nontreated soil) are illustrated in Figure 3.

The threshold of inoculum density for disease to develop was influenced by incubation temperature and bacterial treatment (Fig. 3 ). In control plants grown in infested soil, the maximum DII final value at $25^{\circ} \mathrm{C}$ was attained even at 25 chlamydospores per gram of soil, the lowest of the inoculum densities assayed (Figs. 1 and 3). In contrast, at 20 and $30^{\circ} \mathrm{C}$, which appeared less favorable for disease development, the maximum DII $_{\text {final }}$ was not reached even at 1,000 chlamydospores per gram of soil, the highest inoculum density assayed (Figs. 1 and 3). Bacterial treatments did not modify the overall effect of incubation temperature. However, treatments with Pseudomonas fluorescens RGAF 19 and RG 26 suppressed Fusarium wilt compared with the control when inoculum density of $F$. oxysporum f. sp. ciceris was below 250 chlamydospores per gram of soil and incubation temperature was 20 or $30^{\circ} \mathrm{C}$ (Figs. 1 and 3 ).

When data from all incubation temperature $\times$ bacterial treatment $x$ inoculum density experimental combinations were pooled

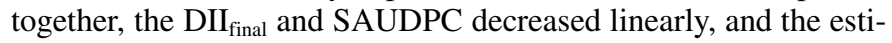
mates of the DII progress rate parameter $r_{G}$ decreased exponentially, with an increase in the time needed for the cumulative DII to reach the inflection point $\left(t_{\mathrm{ip}}\right)$ of the adjusted Gompertz equation (Fig. 4). Data for 20 and $25^{\circ} \mathrm{C}$ incubation temperature 
were described by a fitted equation different from that describing data for $30^{\circ} \mathrm{C}$. Bacterial treatments did not modify the overall effect of incubation temperature on development of Fusarium wilt. Thus, irrespective of the inoculum density of $F$. oxysporum f. sp. ciceris in soil or bacterial treatment, the longest and shortest $t_{\mathrm{ip}}$ occurred for disease reactions developed at 20 and $30^{\circ} \mathrm{C}$, respectively. In addition, for these incubation temperatures, the higher DII $_{\text {final }}$ and SAUDPC values were attained with the higher inoculum densities of the pathogen. In contrast, at $25^{\circ} \mathrm{C}$ there was little variation both in $t_{\text {ip }}$ and in the amount of disease associated with inoculum density or bacterial treatments. At $20^{\circ} \mathrm{C}$, treatments with Pseudomonas fluorescens RGAF 19 and RG 26 strongly delayed disease development in soil with inoculum densities of $F$. oxysporum f. sp. ciceris below 250 chlamydospores per gram of soil compared with the control at the same inoculum densities (Fig. 4), but there were no differences in the amount of disease developed. Conversely, at $30^{\circ} \mathrm{C}$ and low inoculum densities of the pathogen, these same bacterial treatments delayed the $t_{\text {ip }}$ and reduced the DII $_{\text {final }}$ and SAUDPC compared with the controls at the same inoculum densities (Fig. 4). The incubation temperature and pathogen inoculum density also influenced the effect of bacterial treatments on the estimated relative rate of DII progress in the fitted Gompertz equation (Fig. 4). For incubation at 25 and $30^{\circ} \mathrm{C}$, but not for $20^{\circ} \mathrm{C}, r_{G}$ decreased steadily with decreasing inoculum density of $F$. oxysporum f. sp. ciceris. Overall, treatments with bacterial isolates reduced the $r_{G}$ at a given inoculum density compared with the control at the same inoculum density. The lowest $r_{G}$ values occurred in treatments with Pseudomonas fluorescens RGAF 19 and RG 26 at low inoculum density of the pathogen.

\section{DISCUSSION}

Fusarium wilt diseases can be suppressed with introduced rhizobacteria $(7,27,28)$. Efficacy of introduced rhizobacteria in disease suppression may be influenced by factors in the pathosystem $(22,38,40,41)$; however, the influence of temperature on the degree of disease suppression had not been adequately studied in Fusarium wilt diseases. The aim of this work was primarily to assess the effects of temperature and inoculum density of $F$. oxysporum f. sp. ciceris race 5 on the suppression of Fusarium wilt by introduced rhizobacteria.

This study indicates that Pseudomonas fluorescens RGAF 19 and RG 26 were effective in suppressing Fusarium wilt in chickpea to a degree. However, the results further demonstrate that temperature and inoculum density interact to modulate the level of disease suppression by introduced rhizobacteria. Interestingly, the isolates that were better at disease suppression had the least ability to inhibit $F$. oxysporum $\mathrm{f}$. sp. ciceris in vitro. The lack of a general correlation between biocontrol ability of microbial agents and their in vitro antagonistic activity against plant pathogens is well accepted $(10,45)$.

There are several possibilities that can account for the differential effect of temperature and pathogen inoculum density on suppression of Fusarium wilt by rhizobacteria. One is that the pathogen inoculum potential at $25^{\circ} \mathrm{C}$ is just too high to be counteracted by the biocontrol agent, because disease developed best at $25^{\circ} \mathrm{C}$ compared with 20 and $30^{\circ} \mathrm{C}$. At $25^{\circ} \mathrm{C}$, the disease potential seemed saturated with the least of the inoculum densities of $F$. oxysporum f. sp. ciceris in the study, because increasing inoculum density did not increase disease. Navas-Cortés et al. (33) found a similar relationship between disease development and $F$. oxysporum $\mathrm{f}$. sp. ciceris race 5 inoculum density in a study using a $25^{\circ} \mathrm{C}$ incubation temperature only. In this study, in the absence of rhizobacteria, higher numbers of infections were necessary at 20 and $30^{\circ} \mathrm{C}$ compared with $25^{\circ} \mathrm{C}$ for Fusarium wilt to develop early, fast, and severely. When Pseudomonas fluorescens RGAF 19 and RG 26 were introduced with seed and soil, the pathogen inoculum potential must have been reduced because the disease

\section{Incubation temperature}
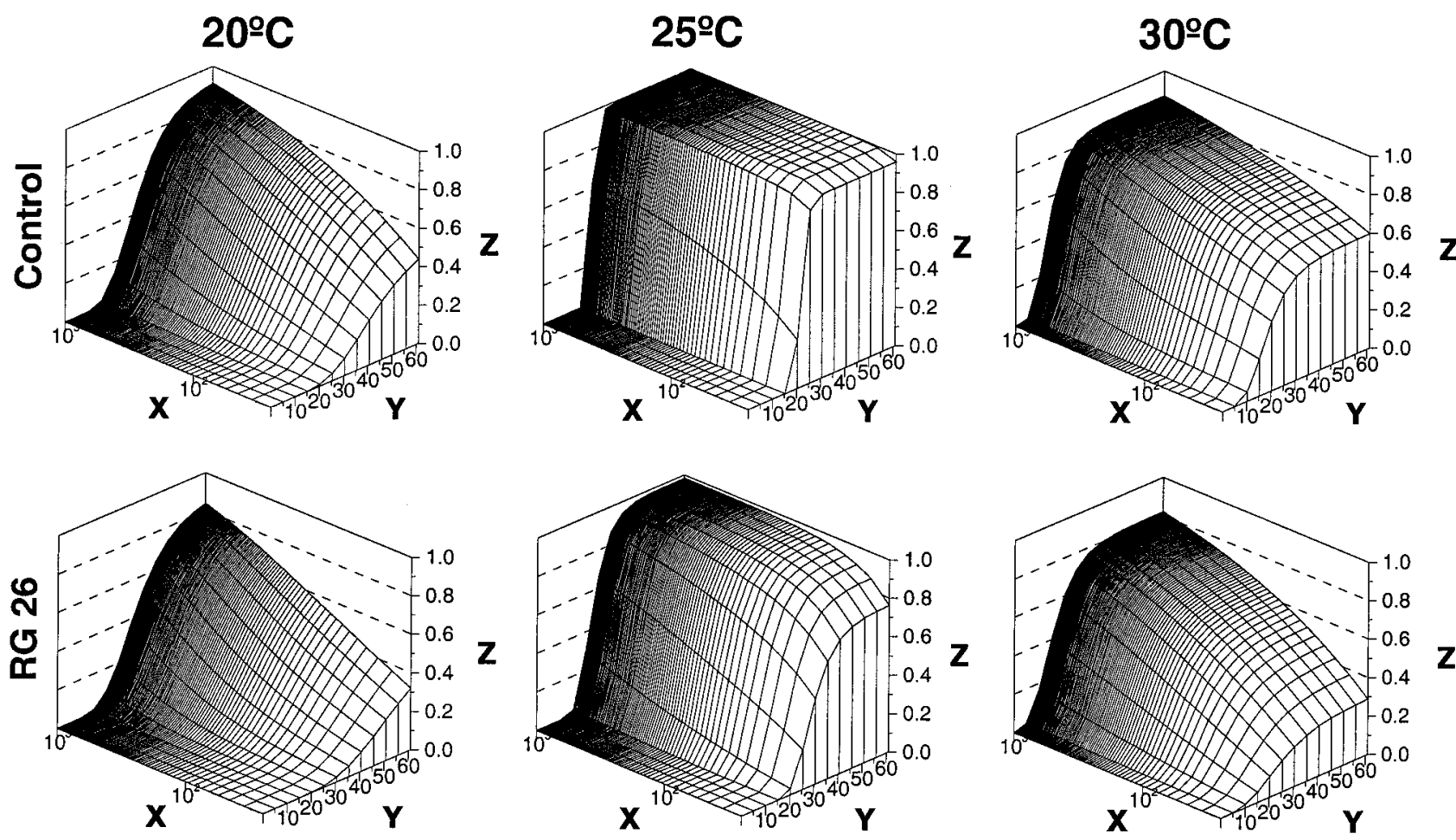

Fig. 3. Surface response for Fusarium wilt disease intensity (Z) in chickpea cv. PV 61 incubated at 20,25 , and $30^{\circ} \mathrm{C}$ after treatment with Pseudomonas fluorescens RG 26, as a function of both inoculum density (25, 50, 100, 250, 500, and 1,000 chlamydospores per gram of soil) of Fusarium oxysporum f. sp. ciceris race $5(\mathrm{X})$ and time (days) from sowing (Y). Nontreated seeds sown in nontreated soil served as controls. 
onset and rate of increase were delayed and slowed down, respectively, compared with the control at 20 and $30^{\circ} \mathrm{C}$ but not at $25^{\circ} \mathrm{C}$. These effects would be expected to occur at 20 and $30^{\circ} \mathrm{C}$, but not at $25^{\circ} \mathrm{C}$, when the inoculum density is reduced in the absence of introduced rhizobacteria. Further, the effects by the introduced rhizobacteria occurred only at low inoculum densities of the pathogen, which suggests a threshold in the extent of reduction of inoculum potential by the rhizobacteria. Thus, as found in previous studies $(18,25)$, valuable Fusarium wilt suppression conferred by seed, soil, or seed + soil treatments with biocontrol agents can be annulled by high inoculum densities of $F$. oxysporum f. sp. ciceris race 5 .

Second, the effect of temperature in modulating Fusarium wilt suppression by the introduced rhizobacteria may also result from an influence of temperature on their activities. Ben-Yephet and Nelson (2) found that the level of suppression of damping-off caused by Pythium spp. in compost treatments was dependent on

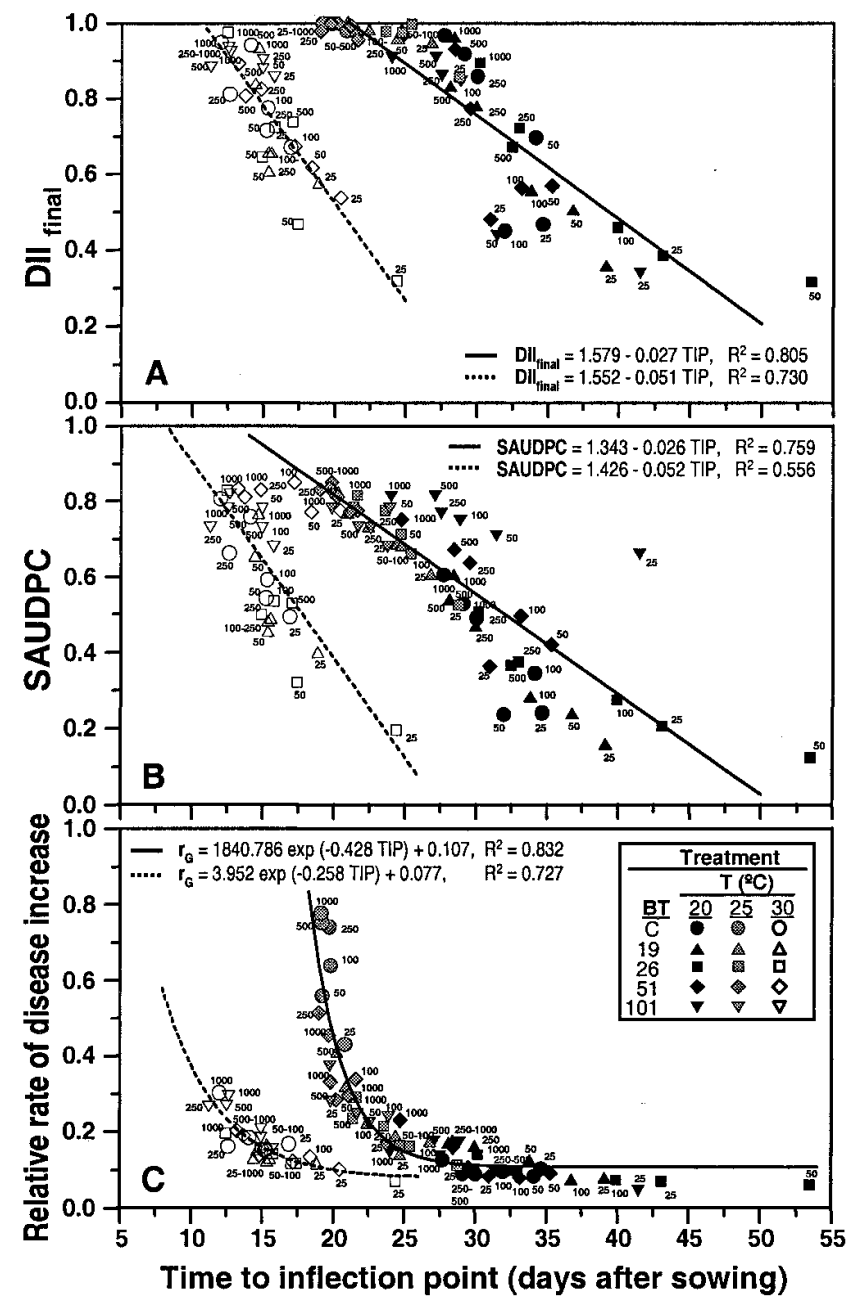

Fig. 4. Effect of bacterial treatments on the relationship between time to reach the inflection point (TIP) and the following parameters for Fusarium wilt progress curves in chickpea cv. PV 61 grown in soil infested with 25, $50,100,250,500$, and 1,000 chlamydospores per gram of soil of Fusarium oxysporum f. sp. ciceris race 5 and incubated at 20,25 , and $30^{\circ} \mathrm{C}$. Bacteria tested (BT) were Pseudomonas fluorescens RGAF 19, Pseudomonas fluorescens RG 26, Bacillus megaterium RGAF 51, and Paenibacillus macerans RGAF 101. Nontreated seeds sown in nontreated soil served as controls. A, Final disease intensity index $\left(\mathrm{DII}_{\text {final }}\right)$. B, Standardized area under the disease progress curve (SAUDPC). C, Estimated relative rate parameter of Gompertz model for DII increase over time $\left(r_{G}\right)$. Lines represent the predicted equation calculated by the linear $\mathbf{A}$ and $\mathbf{B}$, and expanded negative exponential $\mathbf{C}$ models. Numbers displayed near each data point indicate the number of chlamydospores per gram of soil. the incubation temperature; they suggested that this effect may be due in part to different levels of microbial activity in the different composts at the different incubation temperatures. This type of temperature response has also been observed in the biological control of Pythium aphanidermatum by sugar beet rhizobacteria (42). In this latter study, suppression of the pathogen was expressed at $20^{\circ} \mathrm{C}$ but not at $27^{\circ} \mathrm{C}$, and this effect was directly correlated with bacterial activity in the rhizosphere. In our study, the mechanisms involved in the temperature effect on suppression of Fusarium wilt by rhizobacteria are not known yet. We speculate that different temperatures may lead to different levels of rhizosphere establishment and root colonization by the introduced bacteria that relates to biocontrol efficiency. Preliminary studies in our laboratory indicate that endophytic and rhizosphere bacterial colonization, and chickpea emergence and growth promotion by these bacterial isolates, are greatly influenced by temperature (B. B. Landa, J. A. Navas-Cortés, A. Hervás, and R. M. JiménezDíaz, unpublished data). Rapid colonization and persistence in the rhizosphere of introduced biocontrol agents are especially important in biological control of Fusarium wilts because of motile infections courts in these diseases (1). Because many root tips develop during root growth, there is a high likelihood of successful infections in them at optimum conditions for disease such as those in our study. Thus, temperature adequate for efficient disease suppression should reduce the efficacy of pathogen inoculum and yet allow rhizobacteria to cope with root growth in protecting new infection courts.

Results from our study agree with those of other authors in that the efficacy of biocontrol agents in suppressing disease decreases as conditions become more favorable for disease development $(3,22)$. This emphasizes the convenience of integrating the use of rhizobacteria with existing practices for the management of Fusarium wilt in chickpea. Advancing the sowing date from early spring to early winter is a good choice in this strategy because it can delay the onset and slow down the development of epidemics and minimize the final amount of disease (34). Studies are in progress to determine the efficiency of integrating choice of sowing date, chickpea cultivar, and use of rhizobacteria in the management of Fusarium wilt.

Several authors have reported the utility of dose-response models in driving biocontrol research approaches and interpretations $(26,37,40)$. However, pathogen dose and environmental factors (i.e., incubation temperature) influencing the level of pathogen inactivation occurring per unit of biocontrol agent is predicted to radically change the resulting dose-response curves $(21,31)$. Additionally, the microbial environment can influence dramatically microbial functions and performance, and in most cases the influence of these factors on antagonists dose-response has not been studied (40). Application of epidemiological and mathematical models to data of biocontrol experiments should help to clarify the complexities of these interactions and reveal fundamental ecological and biological principles of microbial interactions (37).

Montesinos and Bonaterra (31) pointed out that there is a need for objective means to fit data on infectivity titration of pathogens and biocontrol agents to suitable models that may provide doseresponse surfaces and parameters describing the virulence of the pathogen and the efficiency of the biocontrol agent. In our study, the response surface analysis and epidemiological dose-response models employed were useful for describing, clarifying, and characterizing differences in the efficacy of rhizobacteria on the suppression of Fusarium wilt in chickpea as influenced by incubation temperature and inoculum density of the pathogen. In addition, these observations would help to identify conditions for which treatments with bacterial isolates would potentially improve efficacy in suppressing Fusarium wilt in chickpea.

Recognition of conditions under which biocontrol agents fail in disease control is the first step toward designing approaches to 
combat the problem. Furthermore, the variable efficacy of biological control emphasizes the need to evaluate these agents under variable environmental conditions (3). Results from our study were obtained under conditions of low, moderate, and high disease as influenced by the inoculum density of $F$. oxysporum $\mathrm{f}$. sp. ciceris in soil and incubation temperature. A better understanding of these effects would help in designing new strategies for the efficient use and improved performance of these biocontrol agents.

\section{ACKNOWLEDGMENTS}

Research support was provided by a fellowship from Consejo Superior de Investigaciones Científicas, Spain to B. B. Landa and by grant AGF97-1479 from Comisión Interministerial de Ciencia y Tecnología (CICYT) of Spain. We thank D. M. Weller for a thoughtful review and critical comments on the manuscript.

\section{LITERATURE CITED}

1. Baker, R., and Paulitz, T. C. 1996. Theoretical basis for microbial interactions leading to biological control of soilborne plant pathogens. Pages 50-79 in: Principles and Practice of Managing Soilborne Plant Pathogens. R. Hall, ed. The American Phytopathological Society, St. Paul, MN.

2. Ben-Yephet, Y., and Nelson, E. B. 1999. Differential suppression of damping-off caused by Pythium aphanidermatum, $P$. irregulare, and P. myriotylum in composts at different temperatures. Plant Dis. 83:356360.

3. Boland, G. J. 1997. Stability analysis for evaluating the influence of environment on chemical and biological control of white mold (Sclerotinia sclerotiorum) of bean. Biol. Control 9:7-14.

4. Bouhot, D., and Rouxel, F. 1971. Technique sélective et quantitative d'analyse des Fusarium oxysporum et Fusarium solani dans le sol. Mode d'emploi. Ann. Phytopathol. 3:251-254.

5. Bull, C. T., Weller, D. M., and Thomashow, L. S. 1991. Relationship between root colonization and suppression of Gaeumannomyces graminis var. tritici by Pseudomonas fluorescens strain 2-79. Phytopathology 81:954-959.

6. Campbell, C. L., and Madden, L. V. 1990. Introduction to Plant Disease Epidemiology. John Wiley \& Sons, New York.

7. Chen, C., Bauske, E. M., Musson, G., Rodríguez-Kábana, R., and Kloepper, J. W. 1995. Biological control of Fusarium wilt on cotton by use of endophytic bacteria. Biol. Control 5:83-91.

8. Dik, A. J., and Elad, Y. 1999. Comparison of antagonists of Botrytis cinerea in greenhouse-grown cucumber and tomato under different climatic conditions. Eur. J. Plant Pathol. 105:123-137.

9. Duijff, B. J., Recorbet, G., Bakker, P. A. H. M., Loper, J. E., and Lemanceau, P. 1999. Microbial antagonism at the root level is involved in the suppression of Fusarium wilt by the combination of nonpathogenic Fusarium oxysporum Fo47 and Pseudomonas putida WCS358. Phytopathology 89:1073-1079.

10. Fravel, D. R. 1988. Role of antibiosis in the biocontrol of plant diseases. Annu. Rev. Phytopathol. 26:75-91.

11. Geels, F. P., and Schippers, B. 1983. Reduction of yield depressions in high frequency potato cropping soil after seed tuber treatments with antagonistic fluorescent Pseudomonas spp. Phytopathol. Z. 108: 207-214.

12. Gupta, O., Kotasthane, S. R., and Khare, M. N. 1987. Factors influencing epidemiology of vascular wilt of chickpea. Proc. Natl. Acad. Sci. India 57:86-91.

13. Hannusch, D. J., and Boland, G. J. 1996. Interactions of air temperature, relative humidity and biological control agents on grey mold of bean. Eur. J. Plant Pathol. 102:133-142.

14. Harris, A. R., Siwek, K., and Wiseman, B. M. 1997. Interactions between damping-off fungi, antagonists and Capsicum seedlings. Appl. Soil Ecol. 6:251-263.

15. Hau, B., Eisensmith, S. P., and Kranz, J. 1985. Construction of temporal models. II. Simulation of aerial epidemics. Pages 31-65 in: Advances in Plant Pathology. Vol. 3. C. A. Gilligan, ed. Academic Press, London.

16. Haware, M. P., and Nene, Y. L. 1982. Races of Fusarium oxysporum f. sp. ciceri. Plant Dis. 66:809-810.

17. Hervás, A., Landa, B., Datnoff, L. E., and Jiménez-Díaz, R. M. 1998. Effects of commercial and indigenous microorganisms on Fusarium development in chickpea. Biol. Control 13:166-176.

18. Hervás, A., Landa, B., and Jiménez-Díaz, R. M. 1997. Influence of chickpea genotype and Bacillus sp. on protection from Fusarium wilt by seed treatment with nonpathogenic Fusarium oxysporum. Eur. J. Plant Pathol. 103:631-642.

19. Jalali, B. L., and Chand, H. 1992. Chickpea wilt. Pages 429-444 in: Plant Diseases of International Importance. Vol. 1. Diseases of Cereals and Pulses. U. S. Singh, A. N. Mukhopadhayay, J. Kumar, and H. S. Chaube, eds. Prentice Hall, Englewood Cliffs, NJ.

20. Jiménez-Díaz, R. M., Alcalá-Jiménez, A. R., Hervás, A., and TraperoCasas, J. L. 1993. Pathogenic variability and host resistance in the Fusarium oxysporum f. sp. ciceris/Cicer arietinum pathosystem. Pages 87-94 in: Fusarium Mycotoxins, Taxonomy, Pathogenicity, Host Resistance. Proc. Eur. Sem., 3rd. E. Arseniuk and T. Goral, eds. Plant Breed. Acclim. Inst., Radzikóv, Poland.

21. Johnson, K. B. 1994. Dose-response relationships and inundative biological control. Phytopathology 84:780-784.

22. Kazmar, E. R., Goodman, R. M., Grau, C. R., Johnson, D. W., Nordheim, E. V., Undersander, D. J., and Handelsman, J. 2000. Regression analyses for evaluating the influence of Bacillus cereus on alfalfa yield under variable disease intensity. Phytopathology 90:657-665.

23. King, E. O., Ward, M. K., and Raney, D. E. 1954. Two simple media for the demonstration of pyocyanin and fluorescein. J. Lab. Clin. Med. 44: 301-307.

24. Köhl, J., Lombaers-van der Plas, C. H., Molhoek, W. M. L., Kessel, G. J. T., and Goosen-van der Geijn, H. M. 1999. Competitive ability of the antagonists Ulocladium atrum and Gliocladium roseum at temperatures favourable for Botrytis spp. development. BioControl 44:329346.

25. Landa, B. B., Hervás, A., Bettiol, W., and Jiménez-Díaz, R. M. 1997. Antagonistic activity of bacteria from chickpea rhizosphere against $F u$ sarium oxysporum f. sp. ciceris. Phytoparasitica 25:305-318.

26. Larkin, R. P., and Fravel, D. R. 1999. Mechanisms of action and doseresponse relationships governing biological control of Fusarium wilt of tomato by nonpathogenic Fusarium spp. Phytopathology 89:11521161.

27. Leeman, M., Van Pelt, J. A., Hendrickx, M. J., Scheffer, R. J., Bakker, P. A. H. M., and Schippers, B. 1995. Biocontrol of Fusarium wilt of radish in commercial greenhouse trials by seed treatment with Pseudomonas fluorescens WCS374. Phytopathology 85:1301-1305.

28. Lemanceau, P., and Alabouvette, C. 1993. Suppression of Fusarium wilts by fluorescent Pseudomonads: Mechanisms and applications. Biocontrol Sci. Technol. 3:219-234.

29. Madden, L. V., and Campbell, C. L. 1990. Nonlinear disease progress curves. Pages 181-229 in: Epidemics of Plant Diseases, Mathematical Analysis and Modeling, 2nd ed. Ecological Studies 13. J. Kranz, ed. Springer-Verlag, Berlin.

30. Maniatis, T., Fritsch, E. F., and Sambrook, J. 1982. Molecular Cloning: A Laboratory Manual. Cold Spring Harbor Laboratory, Cold Spring Harbor, NY.

31. Montesinos, E., and Bonaterra, A. 1996. Dose-response models in biological control of plant pathogens: An empirical verification. Phytopathology 86:464-472.

32. Mukherjee, P. K., and Raghu, K. 1997. Effect of temperature on antagonistic and biocontrol potential of Trichoderma sp. on Sclerotium rolfsii. Mycopathologia 139:151-155.

33. Navas-Cortés, J. A., Alcalá-Jiménez, A. R., Hau, B., and Jiménez-Díaz, R. M. 2000. Influence of inoculum density of races 0 and 5 of Fusarium oxysporum f. sp. ciceris on development of Fusarium wilt in chickpea cultivars. Eur. J. Plant Pathol. 106:135-146.

34. Navas-Cortés, J. A., Hau, B., and Jiménez-Díaz, R. M. 1998. Effect of sowing date, host cultivar, and race of Fusarium oxysporum f. sp. ciceris on development of Fusarium wilt of chickpea. Phytopathology 88: 1338-1346.

35. Navas-Cortés, J. A., Hau, B., and Jiménez-Díaz, R. M. 2000. Yield loss in chickpeas in relation to development of Fusarium wilt epidemics. Phytopathology 90:1269-1278.

36. O’Neill, T. M., Niv, A., Elad, Y., and Shtienberg, D. 1996. Biological control of Botrytis cinerea on tomato stem wounds with Trichoderma harzianum. Eur. J. Plant Pathol. 102:635-643.

37. Paulitz, T. C. 2000. Population dynamics of biocontrol agents and pathogens in soils and rhizospheres. Eur. J. Plant Pathol. 106:401-413.

38. Raaijmakers, J. M., Leeman, M., van Oorschot, M. M. P., van der Sluis, I., Schippers, B., and Bakker, P. A. H. M. 1995. Dose-response relationships in biological control of Fusarium wilt of radish by Pseudomonas spp. Phytopathology 85:1075-1081.

39. Saxena, M. C. 1990. Problems and potential of chickpea production in the nineties. Pages 13-27 in: Chickpea in the Nineties: Proc. Int. Workshop Chickpea Improvement, 2nd. International Crop Research Institute for Semi-Arid Tropics, Andhra Pradesh, India.

40. Schisler, D. A., Slininger, P. J., and Bothast, R. J. 1997. Effects of an- 
tagonist cell concentration and two-strain mixtures on biological control of Fusarium dry rot of potatoes. Phytopathology 87:177-183.

41. Smith, K. P., Handelsman, J., and Goodman, R. M. 1999. Genetic basis in plants for interactions with disease-suppressive bacteria. Proc. Natl. Acad. Sci. USA 96:4786-4790.

42. Tedla, T., and Stanghellini, M. E. 1992. Bacterial population dynamics and interactions with Pythium aphanidermatum in intact rhizosphere soil. Phytopathology 82:652-656.
43. Trapero-Casas, A., and Jiménez-Díaz, R. M. 1985. Fungal wilt and root rot diseases of chickpea in southern Spain. Phytopathology 75:11461151.

44. Turner, J. T., and Backman, P. A. 1991. Factors relating to peanut yield increases after seed treatment with Bacillus subtilis. Plant Dis. 75:347353.

45. Weller, D. M. 1988. Biological control of soilborne plant pathogens in the rhizosphere with bacteria. Annu. Rev. Phytopathol. 26:379-407. 